\title{
Health-Related Quality of Life in Patients with Chronic Kidney Disease in Hemodialysis in Medellín (Colombia)
}

This article was published in the following Dove Press journal: Patient Preference and Adherence

\author{
Luis Felipe Higuita- \\ Gutiérrez (1D) \\ Juan José Velasco-Castaño ${ }^{2}$ \\ Judy Natalia Jiménez \\ ${\text { Quiceno } \mathbb{D D}^{3}}^{3}$ \\ 'Facultad de Medicina, Universidad \\ Cooperativa de Colombia, Medellín, \\ Colombia; ${ }^{2}$ Estudiante Escuela de \\ Microbiología, Universidad de Antioquia, \\ Medellín, Colombia; ${ }^{3}$ MICROBA Escuela \\ de Microbiología, Universidad de \\ Antioquia, Medellín, Colombia
}

Correspondence: Luis Felipe HiguitaGutiérrez

Tel +57 4446065 Ext. 4228

Email luis.higuita@campusucc.edu.co
Purpose: Hemodialysis is a treatment that is essential for the survival of patients with terminal chronic kidney disease. However, it is highly invasive, non-curative, and physically, psychologically, socially, and financially demanding, which has an impact on the patient's health-related quality of life (HRQL). In Colombia, research from the point of view of patients undergoing hemodialysis is scarce.

Patients and methods: We conducted a cross-sectional study involving 142 patients undergoing hemodialysis. We used an instrument that included the demographic and clinical information as well as the Charlson Comorbidity Index and Karnofsky Performance Status Scale. HRQL was assessed using EQ-5D-5L and KDQOL-36. The analysis was done using measures of central tendency for quantitative variables and relative frequencies for qualitative variables, in addition bivariate and multivariate regression analyses were conducted.

Results: Based on the scores of the EQ-5D-5L scale, it was found that $14.5 \%$ subjects showed severe mobility problems, $5.8 \%$ were unable to bathe or dress by themselves, $12.9 \%$ were unable to perform usual activities, $13.5 \%$ were experiencing pain or discomfort (between strong and extreme), and 58.6\% showed a certain degree of anxiety or depression. The KDQOL-36 scores were $67.4 \pm 19.4$ for the symptoms domain and $35.0 \pm 27.5$ for the disease burden domain. Results of the linear regression analysis showed that the main factors associated with HRQL were the Karnofsky Index and serum albumin levels $(p<0.05)$.

Conclusion: The result of this study revealed the impact on the quality of life of Colombian patients undergoing hemodialysis with chronic kidney disease who were highly affected by the disease burden. KDQOL-36 has excellent properties of reliability, internal consistency, and discriminant power; thus, its use is recommended in subsequent studies to monitor HRQL in this population.

Keywords: EQ-5D-5L, KDQOL-36, internal consistency, disease burden

\section{Introduction}

Chronic kidney disease (CKD) is a public health issue worldwide owing to the number of people affected, the disabilities it leads to, its mortality rate, and the costs it incurs for health systems. ${ }^{1}$ It is estimated that the prevalence of CKD worldwide is $13.4 \%{ }^{2}$ Disability-adjusted life years increased by $73 \%$ from 1990 to $2013,{ }^{3}$ and the number of deaths rose from 40,900 to 956,000 during the same period. ${ }^{4}$ Regarding costs, it is estimated that approximately $3 \%$ of the healthcare expenditure in developed countries is needed to provide treatment to patients with kidney disease. In 2010, the treatment costs for CKD represented $6.3 \%$ of the health budget in the United States. ${ }^{5}$ 
CKD has 5 progressive stages (CKD-1-CKD-5) based on the levels of kidney damage markers, such as serum albumin, creatinine, and reduced kidney function, as assessed using the glomerular filtration rate. Severe kidney failure that occurs in CKD-5 requires renal replacement therapy. ${ }^{6}$ Among the different renal replacement therapies, hemodialysis is most frequently employed $;^{7}$ despite the fact that it is essential for patient survival, the treatment is highly invasive, non-curative, and physically, psychologically, socially, and financially demanding for patients and their family members. ${ }^{8}$

The physical adverse effects include insomnia, fatigue, loss of mobility, muscle pain, dry skin, and vomiting. Reported psychological effects are depression, anxiety, loss of independence, and low self-esteem. ${ }^{8}$ In financial terms, work/occupational status, possibility of losing one's job, and out-of-pocket expenditure are affected. In the social sphere, inability to perform daily tasks and the impact on family and couple relationships were also observed. ${ }^{8}$

In addition, patients undergoing hemodialysis must follow strict diets, restrict their liquid intake, and take drugs frequently. ${ }^{9}$ Moreover, they are at a high risk of acquiring bacterial infections owing to their relative immunodeficiency and the need for a permanent vascular access. ${ }^{10}$ All of the above factors lead to a decline in the quality of life of people with this disease.

The World Health Organization defines quality of life as a multidimensional construct that includes the individual's perception of their physical health, emotional status, and social relationships ${ }^{11}$ and health-related quality of life (HRQL) as the changes occurring in different dimensions of the quality of life owing to the disease, treatments, lesions, and disabilities. ${ }^{12}$

HRQL has gained relevance in clinical practice owing to the fact that it goes beyond the physical sphere and takes the patient's preferences into account. Hence, it has become a key element to identify changes in the health status, describe disease progression, guide therapeutic decision-making, evaluate clinical trial results, assess medical interventions, optimize allocation of resources, and facilitate communication between the affected individuals and health-care staff members. ${ }^{13,14}$

Some European countries, such as Spain, ${ }^{15}$ the United States, ${ }^{16}$ and some Latin American countries ${ }^{17-19}$ have been conducting research about HRQL in patients with CKD undergoing hemodialysis.
In Colombia, there are approximately 19,388 patients with CKD undergoing hemodialysis, ${ }^{20}$ and chronic kidney disease requires approximately $4 \%$ of the overall health expenditure in Colombia. ${ }^{6}$ Local research regarding this topic is scarce, does not include the psychometric properties of the scale used, and omits some factors associated with the population's HRQL. Therefore, we designed this study to describe the profile of HRQL and its associated factors and included a group of individuals on hemodialysis with CKD from Medellín in 2018.

\section{Materials and Methods Type of Study}

Cross-sectional descriptive study

\section{Study Population}

We considered all patients diagnosed with CKD and on hemodialysis, both male and female, over the age of 18 years, who belonged to a renal unit from a single medical center in Medellín, Colombia in a twelve-month period from November 2017 to December 2018. The renal unit had 230 adults, with CKD and on hemodialysis. All the individuals were invited to participate; however, 15 of them refused. Five patients were excluded because they had a mental or neurological condition that prevented them from completing the survey. For this purpose, 210 forms were distributed, of which 68 were not returned to the researchers (Figure 1).

\section{Information Sources}

\section{Instrument of Sociodemographic and Clinical Variables}

The sociodemographic and clinical data of the patients included in the study were gathered via review of medical records. In the instrument, we included information on sociodemographic characteristics and on infections, comorbidities, and hospitalizations. To measure the severity of the comorbidities, we used the Charlson Comorbidity Index, which includes 19 chronic diseases with a score of 1-6 according to their severity; higher the score, higher the comorbidity. This index predicts one-year mortality risks. ${ }^{21}$

Additionally, we also used the Karnofsky Index to assess the patient's functional status. This scale has a score from 100 (normality) to 0 (dead). Patients with a score of $\geq 60$ are able to meet most of their needs, whereas patients with a score of $\leq 30$ need active support. ${ }^{22}$ 


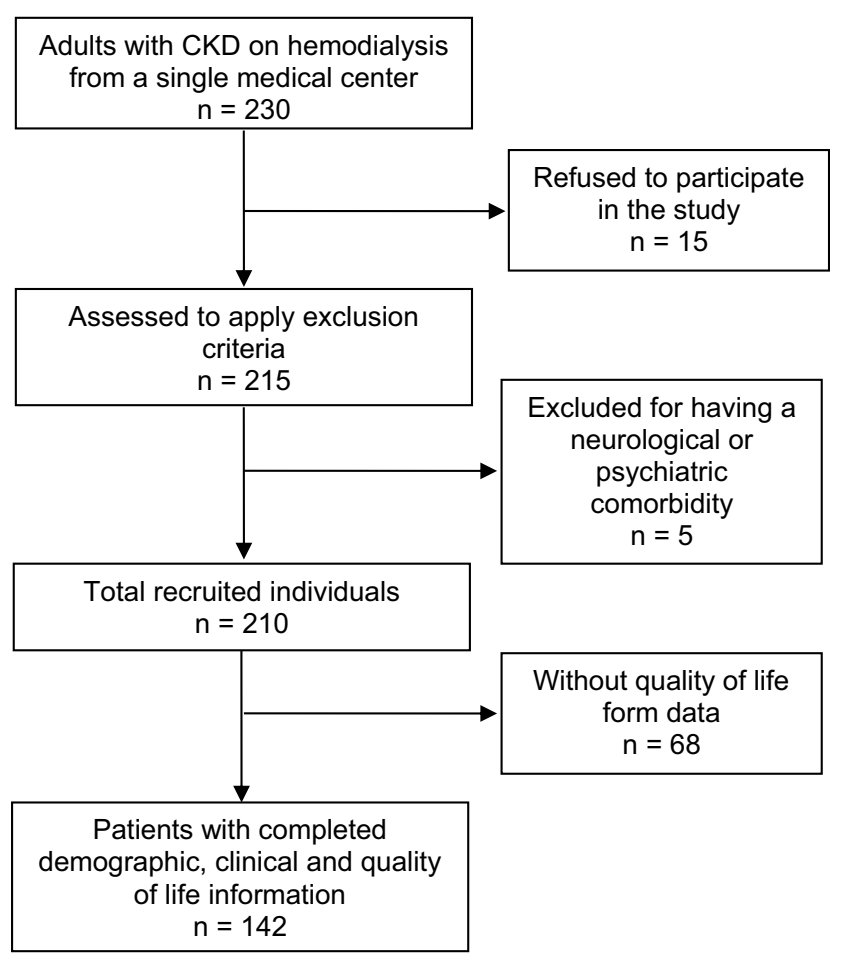

Figure I Participants' selection process.

\section{Health Relate Quality of Life Instruments EQ-5D-5L: Generic Instrument for Health Relate Quality of Life}

EQ-5D-5L is a quality-of-life generic instrument that comprises five dimensions (mobility, self-care, usual activities, pain/discomfort, and anxiety/depression); each of them with five levels (no problems, slight problems, moderate problems, severe problems, and extreme problems). With this instrument, it is possible to describe a total of 3125 states of health, and it has been widely applied worldwide to assess different diseases. ${ }^{23}$

\section{KDQOL-36: HRQL in Patients with CKD Undergoing Hemodialysis}

We used KDQOL-36, which contains SF-12, as the generic core that measures physical and mental functions and KSQOL as the specific core that contains three domains: symptoms and problems, effects of kidney diseases, and kidney disease burden. The scores of this instrument range from 0 (worst state) to 100 (best state). ${ }^{24,25}$ In Colombia, a transcultural adaptation of this questionnaire is used. ${ }^{9}$

\section{Information Analysis}

Sociodemographic and clinical features and quality of life scores were described using proportion or frequencies calculation and summary measures. For the quantitative variables, we defined data distribution using the Kolmogorov-Smirnov test with Lilliefors correction. Bivariate analysis was performed to compare the profile of quality of life according to the clinical and sociodemographic variables. We performed Student's $t$-tests or Mann-Whitney $U$-tests and one-way parametric ANOVA or Kruskal-Wallis $H$-test and measured Pearson or Spearman correlation coefficients. The decision of using parametric or non-parametric tests was based on the validation of the assumption of normality. Regarding ANOVA, we also evaluated the assumption of homoscedasticity using Levene's test. The psychometric assessment of the scale was performed using internal consistency, reliability, and discriminant power criteria. Finally, we performed linear regression analysis to evaluate the impact of potential confounders. For this purpose, we took each of the domains of the KDOQL-36 scale as dependent variables. All the analyses were performed using SPSS (version 25.0 ), and $p$-values of $<0.05$ were considered significant.

\section{Ethical Considerations}

The project complies with the World Medical Association's Declaration of Helsinki. This study is classified as a non-risk research in accordance with Ruling 8430 from 1993 by the Colombian Ministry of Health. It has been endorsed by SIU's Bioethics Committee, memorandum of approval: 17-65-689, May 3, 2017, and all participants provided written informed consent.

\section{Results}

We included 142 patients aged 20-92 (mean: $61.0 \pm 16.0$ ) years; $50.7 \%(n=72)$ were women, and $57 \%(n=81)$ belonged to the lower socioeconomic class. The most frequently occurring comorbidity was high blood pressure $[92.3 \%(\mathrm{n}=131)$ subjects], followed by diabetes [43\% $(\mathrm{n}=61)$ subjects], and $50 \%$ of the patients had a Charlson Index of $\geq 6$ (Table 1 ).

Regarding the domains of the EQ-5D-5L scale, we found that $14.5 \%(n=20)$ of patients have severe mobility problems, $3.6 \%(\mathrm{n}=5)$ are unable to walk, $5.8 \%(\mathrm{n}=8)$ are unable to bathe or dress by themselves and $12.9 \%(n=18)$ are unable to perform usual activities. The experience pain or discomfort and degree of anxiety or depression are seen in Figure 2.

Before using KDQOL-36 to describe HRQL, we evaluated its psychometric properties and found excellent results with respect to reliability, internal consistency, and discriminant power (Table 2). The HRQL scores indicate that symptom management is acceptable (67.4 \pm 19.4$)$ 
Table I Description of the Study Population

\begin{tabular}{|c|c|c|c|}
\hline & Variables & $\mathbf{n}$ & $\%(95 \% \mathrm{Cl})$ \\
\hline \multirow[t]{2}{*}{ Sex } & Female & 72 & $50.7(42.5-58.8)$ \\
\hline & Male & 70 & $49.3(41.2-57.5)$ \\
\hline \multirow[t]{3}{*}{ Class } & Lower & 81 & $57.0(48.8-65.0)$ \\
\hline & Middle & 56 & $39.4(31.7-47.6)$ \\
\hline & Upper & 5 & $3.5(1.4-7.5)$ \\
\hline \multirow[t]{8}{*}{ Comorbidities } & Malignant tumor in solid organ & 8 & $5.6(2.7-10.3)$ \\
\hline & COPD & 10 & $7.0(3.7-12.1)$ \\
\hline & Diabetes mellitus & 61 & $43.0(35.0-51.2)$ \\
\hline & Heart failure & 31 & $21.8(15.6-29.1)$ \\
\hline & Coronary artery disease & 28 & $19.7(13.8-26.8)$ \\
\hline & Peripheral arterial disease & 14 & $9.9(5.8-15.6)$ \\
\hline & Connective tissue disorder & 9 & $6.3(3.2-11.2)$ \\
\hline & High blood pressure & 131 & $92.3(87.0-95.8)$ \\
\hline \multirow[t]{2}{*}{ Catheter } & Temporary dialysis catheter & 11 & $7.7(4.2-13.0)$ \\
\hline & Refusal to use a fistula & 45 & $32.1(24.8-40.2)$ \\
\hline \multirow[t]{3}{*}{ Medical history } & Surgery in the last year & 32 & $22.5(16.3-29.9)$ \\
\hline & Solid organ transplant & 19 & | $3.4(8.5-19.7)$ \\
\hline & Admission to the Intensive Care Unit & 32 & $22.5(16.3-29.9)$ \\
\hline \multirow[t]{2}{*}{ Conditions or therapies } & Immunosuppressants & 21 & $\mid 4.8(9.7-2 \mid .3)$ \\
\hline & Use of antibiotics & 63 & $55.6(36.4-52.6)$ \\
\hline \multirow{7}{*}{$\begin{array}{l}\text { Age } \\
\text { Number of cohabitants } \\
\text { Charlson Index (study) } \\
\text { Karnofsky Index } \\
\text { Serum albumin } \\
\text { Hemoglobin }\end{array}$} & Mean \pm SD & Median (IQR) & Minimum-Maximum \\
\hline & $61.3 \pm 16.1$ & - & $20.0-92.0$ \\
\hline & $4.7 \pm 4.7$ & - & $1.0-40.0$ \\
\hline & - & $6.0(4.0-7.0)$ & $2.0-12.0$ \\
\hline & - & $80.0(80.0-90.0)$ & $40.0-90.0$ \\
\hline & $3.9 \pm 0.6$ & - & $1.9-5.1$ \\
\hline & $11.0 \pm 2.0$ & - & $6.0-18.0$ \\
\hline
\end{tabular}

Abbreviations: COPD, chronic obstructive pulmonary disease; IQR, interquartile range.

and that the most affected domain is the disease burden, with a mean of $35.0 \pm 27.5$, which indicates that the disease significantly interferes with the daily lives of patients and their family members (Table 2).

When analyzing the HRQL profile based on sociodemographic and clinical aspects, we found that patients whose physical and mental health were the most affected (SF-12) were those with COPD, diabetes, temporary dialysis catheter, a higher Charlson Index, a higher number of cohabitants, a lower Karnofsky Index, and lower levels of serum albumin and hemoglobin. The disease burden is significantly higher in patients with diabetes, higher Charlson Index, lower Karnofsky Index, and a lower level of serum albumin. The most symptomatic patients are those with a history of heart attack/revascularization and temporary dialysis catheter, who have accepted the use of a fistula, who had more cohabitants, a higher Charlson Index, a lower Karnofsky Index, and lower levels of serum albumin and hemoglobin. Finally, the impact of kidney diseases on the diet, ability to travel and work, dependence 


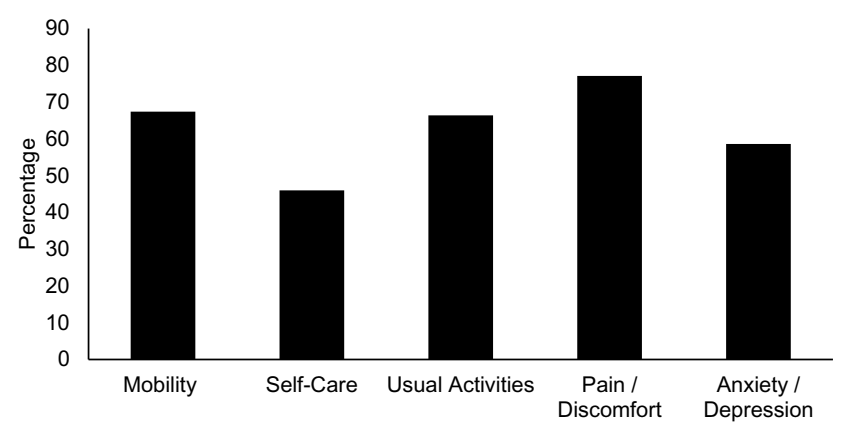

Figure 2 Percentage of population with problems in each of the EQ-5D-5L domains.

on health-care staff members, stress or concerns, sexuality, and image (domain of kidney disease) is more evident in patients with diabetes, history of heart attack/revascularization, temporary dialysis catheter, a higher Charlson Index, a lower Karnofsky Index, and lower serum albumin levels (Tables 3-4).

In linear regression models, we observed that the variables that remained associated with HRQL were the serum albumin levels, Karnofsky Index, history of heart attack/revascularization, refusal to use a fistula, and number of cohabitants; the serum albumin levels and Karnofsky Index were the most relevant ones (Table 5).

\section{Discussion}

The results of this study revealed that patients undergoing hemodialysis have low scores in the domains of physical

Table 2 Description of the HRQL Profile and Psychometric Assessment of the Scale

\begin{tabular}{|c|c|c|c|c|}
\hline & SF-I 2 & $\begin{array}{l}\text { Disease } \\
\text { Burden }\end{array}$ & Symptoms & $\begin{array}{l}\text { Kidney } \\
\text { Disease }\end{array}$ \\
\hline Mean \pm SD & $48.9 \pm 22.3$ & $35.0 \pm 27.5$ & $67.4 \pm 19.4$ & $50.8 \pm 25.2$ \\
\hline Range & $0-100$ & $0-100$ & $0-100$ & $0-100$ \\
\hline Minimum (\%) & 0.8 & 10.6 & 0.8 & 0.7 \\
\hline Maximum (\%) & 0.8 & 5.7 & 1.6 & 1.5 \\
\hline $\begin{array}{l}\text { Cronbach's } \\
\text { alpha }\end{array}$ & 0.7 & 0.8 & 0.7 & 0.8 \\
\hline $\begin{array}{l}\text { Correlation } \\
\text { range item- } \\
\text { domain }\end{array}$ & $0.5-0.8$ & $0.7-0.8$ & $0.5-0.7$ & $0.5-0.8$ \\
\hline $\begin{array}{l}\% \text { of success for } \\
\text { internal } \\
\text { consistency }\end{array}$ & $100(12 / 12)$ & $100(4 / 4)$ & $100(12 / 12)$ & $100(8 / 8)$ \\
\hline $\begin{array}{l}\text { Correlation } \\
\text { range item- } \\
\text { other domain }\end{array}$ & $0.2-0.5$ & $0.3-0.4$ & $0.2-0.6$ & $0.2-0.6$ \\
\hline $\begin{array}{l}\% \text { success for } \\
\text { discriminant } \\
\text { validity }\end{array}$ & $1000(36 / 36)$ & $100(12 / 12)$ & $100(36 / 36)$ & $100(24 / 24)$ \\
\hline
\end{tabular}

Abbreviations: SD, standard deviation; IQR, interquartile range. and mental health (SF-12), disease burden, disease symptoms, and effects of kidney diseases. In the domain of physical and mental health (SF-12), the mean score was $48.9 \pm 22.3$ points. This finding agrees with that of a study including 240,343 patients undergoing hemodialysis from the United States, which indicates that the scores on these subscales are between 36.6 and 49 points. $^{26}$ The results disagree with that of a study conducted in South African in which the score was approximately 60 points. ${ }^{27}$ The low scores in this domain are attributed to the fact that there is a close relationship between the physical disturbances (anemia, metabolite variances, pain, limited mobility, and fatigue after dialysis) and psychosocial disturbances (increased anxiety, work and economic concerns, limited access to transport, marital disagreements, difficulties with medical insurance, and depression) of patients with CKD undergoing hemodialysis. Psychological disturbances are linked to non-adherence to treatment and malnutrition. ${ }^{28,29}$ In fact, in cohort studies, the results in the SF-12 dimension have proven a strong link between mortality and future hospitalizations in this type of patients. Hence, its use has been suggested to establish clinical prognosis. ${ }^{16}$ For such patients, we suggest that monitoring and care of their physical health should be complemented with the follow-up and care of their mental health.

In the domain of the disease symptoms, we obtained a score of $67.4 \pm 19.4$ points. This domain considers the previous month's frequencies of muscle pain, cramps, skin itchiness and dryness, fainting or dizziness, loss of appetite, nausea, or problems with vascular access. In this study, one of the most frequent symptoms was pruritus, with $75 \%$ patients experiencing it to a certain degree. Results of previous studies indicate that this is a symptom that most often exhibited by patients with terminal kidney disease undergoing hemodialysis, and it can be exhibited by $40-90 \%$ patients. However, this condition is frequently underdiagnosed and poorly managed. ${ }^{30}$ In this regard, pruritus has negative effects on the quality of life beyond the discomfort caused by the condition (undergoing hemodialysis), including fatigue, low-quality sleep, and depression. Moreover, it has been associated with worse prognosis and mortality; for example, patients with pruritus may have a higher rate of missed dialysis sessions, resulting in a higher risk of hospitalization or death. ${ }^{30,31}$ Taking the above into account, pruritus has been established as a priority when managing patients with CKD. However, its pathophysiology is still unclear, the optimal treatment is not well established, and the evidence of the 
Table 3 Comparison of HRQL with Demographic and Clinical Variables

\begin{tabular}{|c|c|c|c|c|c|}
\hline & & SF-I 2 & Disease Burden & Symptoms & Kidney Disease \\
\hline \multirow[t]{2}{*}{ Sex } & Female & $49.6 \pm 21.1^{\mathrm{a}}$ & $37.5(12.5-56.3)^{\mathrm{b}}$ & $68.1 \pm 18.2^{\mathrm{a}}$ & $51.6 \pm 25.0^{\mathrm{a}}$ \\
\hline & Male & $48.2 \pm 23.7^{\mathrm{a}}$ & $25.0(12.5-43.8)^{\mathrm{b}}$ & $66.6 \pm 20.7^{\mathrm{a}}$ & $49.9 \pm 25.6^{\mathrm{a}}$ \\
\hline \multirow[t]{3}{*}{ Socioeconomic class } & Lower & $48.8 \pm 23.3^{d}$ & $25.0(6.3-43.8)^{c}$ & $64.6 \pm 22.1^{d}$ & $50.2 \pm 25.3^{d}$ \\
\hline & Middle & $48.7 \pm 21.3^{d}$ & $31.3(21.9-50.0)^{c}$ & $71.2 \pm 13.9^{d}$ & $50.4 \pm 24.5^{d}$ \\
\hline & Upper & $41.9 \pm 22.8^{d}$ & $46.9(\mid 8.8-78.1)^{c}$ & $63.0 \pm 18.7^{d}$ & $59.4 \pm 27.4^{d}$ \\
\hline \multirow[t]{2}{*}{ Smoking } & No & $50.5 \pm 21.1^{\mathrm{a}}$ & $31.3(12.5-62.5)^{\mathrm{b}}$ & $70.0 \pm 17.7^{\mathrm{a}}$ & $53.7 \pm 25.0^{a}$ \\
\hline & Yes & $46.9 \pm 23.3^{\mathrm{a}}$ & $31.3(12.5-43.8)^{\mathrm{b}}$ & $63.8 \pm 21.0^{\mathrm{a}}$ & $47.6 \pm 25.3^{\mathrm{a}}$ \\
\hline \multirow[t]{2}{*}{ Malignant tumor in solid organ } & No & $48.3 \pm 21.9^{\mathrm{a}}$ & $31.3(12.5-50.0) \mathrm{b}$ & $67.3 \pm 19.5^{\mathrm{a}}$ & $50.6 \pm 25.5^{\mathrm{a}}$ \\
\hline & Yes & $59.0 \pm 29.0$ & $31.3(12.5-37.5)^{\mathrm{b}}$ & $68.0 \pm 19.5^{\mathrm{a}}$ & $54.5 \pm 20.6^{\mathrm{a}}$ \\
\hline \multirow[t]{2}{*}{ COPD } & No & $50.4 \pm 22.3^{\mathrm{a}, * *}$ & $31.3(12.5-50.0)^{\mathrm{b}}$ & $67.4 \pm 19.3^{\mathrm{a}}$ & $51.6 \pm 25.1^{a}$ \\
\hline & Yes & $29.4 \pm 10.8^{\mathrm{a}, * *}$ & $18.8(0.0-37.5)^{\mathrm{b}}$ & $66.7 \pm 22.2^{\mathrm{a}}$ & $39.6 \pm 26.2^{\mathrm{a}}$ \\
\hline \multirow[t]{2}{*}{ Diabetes mellitus } & No & $53.9 \pm 22.0^{\mathrm{a}, * *}$ & $31.3(18.8-62.5)^{\mathrm{b}, *}$ & $72.9(56.3-83.3)$ & $55.6 \pm 23.8^{\mathrm{a}, *}$ \\
\hline & Yes & $42.1 \pm 21.1^{\mathrm{a}, * *}$ & $25.0(6.3-37.5)^{\mathrm{b}, *}$ & $64.6(52.1-79.2)$ & $44.5 \pm 25.8^{\mathrm{a}, *}$ \\
\hline \multirow[t]{2}{*}{ Heart failure } & No & $49.2 \pm 23.2^{\mathrm{a}}$ & $31.3(12.5-50.0)^{\mathrm{b}}$ & $68.7 \pm 18.8^{\mathrm{a}}$ & $52.2 \pm 24.7^{\mathrm{a}}$ \\
\hline & Yes & $47.9 \pm 19.6^{\mathrm{a}}$ & $25.0(12.5-43.8)^{\mathrm{b}}$ & $62.3 \pm 20.8^{\mathrm{a}}$ & $45.7 \pm 26.8^{a}$ \\
\hline \multirow[t]{2}{*}{ Heart attack/revascularization } & No & $50.4 \pm 22.5^{\mathrm{a}}$ & $31.3(12.5-56.3)^{\mathrm{b}}$ & $72.9(56.3-83.3)^{*}$ & $53.1 \pm 24.7^{\mathrm{a}, *}$ \\
\hline & Yes & $43.1 \pm 21.2^{\mathrm{a}}$ & $25.0(9.4-34.4)^{\mathrm{b}}$ & $62.5(52.1-72.9)^{*}$ & $42.2 \pm 25.7^{\mathrm{a}, *}$ \\
\hline \multirow[t]{2}{*}{ Peripheral arterial disease } & No & $50.0 \pm 22.3^{\mathrm{a}}$ & $31.3(12.5-50.0)^{\mathrm{b}}$ & $71.9(52.1-81.3)^{\mathrm{b}}$ & $50.8 \pm 25.4^{\mathrm{a}}$ \\
\hline & Yes & $37.2 \pm 19.6^{\mathrm{a}}$ & $31.3(25.0-56.3)^{\mathrm{b}}$ & $64.6(56.3-79.2)^{\mathrm{b}}$ & $50.3 \pm 24.9^{\mathrm{a}}$ \\
\hline \multirow[t]{2}{*}{ Connective tissue disorder } & No & $49.1 \pm 22.2^{\mathrm{a}}$ & $31.3(12.5-50.0)^{\mathrm{b}}$ & $67.1 \pm 19.3^{\mathrm{a}}$ & $53.1(31.3-68.8)^{\mathrm{b}}$ \\
\hline & Yes & $47.0 \pm 25.0^{\mathrm{a}}$ & $25.0(6.3-50.0)^{\mathrm{b}}$ & $71.1 \pm 21.6^{\mathrm{a}}$ & $56.3(21.9-62.5)^{\mathrm{b}}$ \\
\hline \multirow[t]{2}{*}{ High blood pressure } & No & $59.7 \pm 29.5^{\mathrm{a}}$ & $37.5(12.5-62.5)^{\mathrm{b}}$ & $68.5 \pm 17.4^{\mathrm{a}}$ & $53.4 \pm 35.8^{\mathrm{a}}$ \\
\hline & Yes & $48.0 \pm 21.5^{\mathrm{a}}$ & $31.3(12.5-50.0)^{\mathrm{b}}$ & $67.3 \pm 19.6^{\mathrm{a}}$ & $50.6 \pm 24.4^{\mathrm{a}}$ \\
\hline \multirow[t]{2}{*}{ Temporary dialysis catheter } & No & $50.1 \pm 22.3^{\mathrm{a}, *}$ & $31.3(12.5-50.0)^{\mathrm{b}}$ & $71.9(55.2-2.3)^{\mathrm{b}, *}$ & $52.2 \pm 24.4^{\mathrm{a}, *}$ \\
\hline & Yes & $35.5 \pm 19.5^{\mathrm{a}, *}$ & $37.5(0.0-50.0)^{\mathrm{b}}$ & $56.3(47.9-64.6)^{\mathrm{b}, *}$ & $34.7 \pm 29.9^{\mathrm{a}, *}$ \\
\hline \multirow[t]{2}{*}{ Refusal to use a fistula } & No & $47.5 \pm 22.1^{\mathrm{a}}$ & $31.3(12.5-43.8)^{\mathrm{b}}$ & $64.8 \pm 19.9^{\mathrm{a}, *}$ & $53.1(28.1-68.8)^{\mathrm{b}}$ \\
\hline & Yes & $52.5 \pm 22.6^{a}$ & $31.3(18.8-62.5)^{\mathrm{b}}$ & $72.8 \pm 16.5^{a, *}$ & $56.3(37.5-78.1)^{\mathrm{b}}$ \\
\hline \multirow[t]{2}{*}{ Surgery in the last year } & No & $49.521 .8^{\mathrm{a}}$ & $31.3(12.5-46.9)^{\mathrm{b}}$ & $70.8(52.1-81.3)^{b}$ & $51.3 \pm 25.4^{\mathrm{a}}$ \\
\hline & Yes & $47.2 \pm 24.1^{a}$ & $31.3(12.5-56.3)^{\mathrm{b}}$ & $68.8(56.3-81.3)^{\mathrm{b}}$ & $49.0 \pm 25.0^{\mathrm{a}}$ \\
\hline \multirow[t]{2}{*}{ Transplant history } & No & $48.2 \pm 22.4^{\mathrm{a}}$ & $31.3(12.5-50.0)^{\mathrm{b}}$ & $67.4 \pm 19.6^{\mathrm{a}}$ & $51.3 \pm 25.3^{\mathrm{a}}$ \\
\hline & Yes & $53.0 \pm 21.9^{\mathrm{a}}$ & $18.8(12.5-56.3)^{\mathrm{b}}$ & $67.3 \pm 18.4^{\mathrm{a}}$ & $47.4 \pm 25.2^{\mathrm{a}}$ \\
\hline \multirow[t]{2}{*}{ Hospitalization } & No & $51.0 \pm 21.6^{\mathrm{a}}$ & $37.5(12.5-62.5)^{\mathrm{b}}$ & $69.5 \pm 17.8^{\mathrm{a}}$ & $53.8 \pm 25.4^{\mathrm{a}}$ \\
\hline & Yes & $47.5 \pm 22.8^{\mathrm{a}}$ & $25.0(12.5-43.8)^{\mathrm{b}}$ & $66.0 \pm 20.3^{\mathrm{a}}$ & $48.8 \pm 25.1^{a}$ \\
\hline
\end{tabular}

(Continued) 
Table 3 (Continued).

\begin{tabular}{|l|l|l|l|l|l|}
\hline \multicolumn{2}{|c|}{} & SF-I 2 & Disease Burden & Symptoms & Kidney Disease \\
\hline \multirow{2}{*}{ Admission to the intensive care unit } & No & $49.5 \pm 21.4^{\mathrm{a}}$ & $31.3(12.5-50.0)^{\mathrm{b}}$ & $67.6 \pm 18.6^{\mathrm{a}}$ & $56.3(31.3-68.8)^{\mathrm{b}}$ \\
\cline { 2 - 6 } & Yes & $46.7 \pm 25.8^{\mathrm{a}}$ & $25.0(12.5-37.5)^{\mathrm{b}}$ & $66.7 \pm 22.3^{\mathrm{a}}$ & $50.0(25.0-68.8)^{\mathrm{b}}$ \\
\hline \multirow{2}{*}{ Immunosuppressants } & No & $48.5 \pm 22.6^{\mathrm{a}}$ & $31.3(12.5-50.0)^{\mathrm{b}}$ & $71.9(55.2-81.3)^{\mathrm{b}}$ & $50.7 \pm 25.6^{\mathrm{a}}$ \\
\cline { 2 - 6 } & Yes & $51.0 \pm 21.2^{\mathrm{a}}$ & $37.5(12.5-56.3)^{\mathrm{b}}$ & $64.6(47.9-83.3)^{\mathrm{b}}$ & $51.0 \pm 23.9^{\mathrm{a}}$ \\
\hline \multirow{2}{*}{ Use of antibiotics } & No & $50.4 \pm 24.1^{\mathrm{a}}$ & $31.3(12.5-50.0)^{\mathrm{b}}$ & $67.9 \pm 19.8^{\mathrm{a}}$ & $50.2 \pm 25.5^{\mathrm{a}}$ \\
\cline { 2 - 6 } & Yes & $47.2 \pm 20.3^{\mathrm{a}}$ & $31.3(12.5-50.0)^{\mathrm{b}}$ & $68.0 \pm 18.6^{\mathrm{a}}$ & $52.2 \pm 25.3^{\mathrm{a}}$ \\
\hline
\end{tabular}

Notes: ${ }^{a}$ Student's $t$-test compares mean figures, ${ }^{b}$ Mann-Whitney $U$-test compares median figures, ${ }^{\mathrm{c} K r u s k a l-W a l l i s ~} H$-test, ${ }^{\mathrm{d}} \mathrm{ANOVA}$, ${ }^{\mathrm{P}} \mathrm{P}<0.05$, ${ }^{* *} \mathrm{p}<0.0 \mathrm{I}$.

Table 4 Correlation Coefficients Between HRQL Dimensions and Clinical and Demographic Variables

\begin{tabular}{|l|l|l|l|l|}
\hline & SFI2 & Disease Burden & Symptoms & Kidney Disease \\
\hline Age & $-0.1^{\mathrm{a}}$ & $-0.1^{\mathrm{a}}$ & $-0.0^{\mathrm{a}}$ & $-0 . I^{\mathrm{a}}$ \\
Number of cohabitants & $-0.2^{\mathrm{a}, *}$ & $-0.2^{\mathrm{a}, *}$ & $-0.2^{\mathrm{a}, *}$ & $-0 . .^{\mathrm{a}}$ \\
Charlson Index & $-0.2^{\mathrm{a}, *}$ & $-0.2^{\mathrm{a}, *}$ & $-0.1^{\mathrm{a}}$ & $-0.2^{\mathrm{a}, *}$ \\
Karnofsky Index & $0.5^{\mathrm{a}, * *}$ & $0.2^{\mathrm{a}, * *}$ & $0.2^{\mathrm{a}, *}$ & $0.3^{\mathrm{a}, * *}$ \\
Serum albumin & $0.4^{\mathrm{a}, * *}$ & $0.2^{\mathrm{a}, *}$ & $0.3^{\mathrm{a}, * *}$ & $0.3^{\mathrm{a}, * *}$ \\
Hemoglobin & $0.2^{\mathrm{a}, *}$ & $0.0^{\mathrm{a}}$ & $0.2^{\mathrm{a}, *}$ & $-0.1^{\mathrm{a}}$ \\
\hline
\end{tabular}

Notes: ${ }^{a}$ Spearman correlation, ${ }^{*} p<0.05 *^{*} p<0.01$.

available therapeutic options is poor. ${ }^{32}$ Therefore, it is necessary to promote more research in this field.

In the domain of the disease effects, we obtained a score of $50.8 \pm 25.2$ points. This domain takes into account the extent to which kidney diseases affect the

Table 5 Linear Regression Models for Each of the HRQL Dimensions

\begin{tabular}{|l|l|l|l|}
\hline Dimension & $\begin{array}{l}\text { Model } \\
\text { Variables }\end{array}$ & $\begin{array}{l}\text { Regression } \\
\text { Coefficient }\end{array}$ & $\begin{array}{l}\text { Coefficient of } \\
\text { Determination }\end{array}$ \\
\hline \multirow{2}{*}{ SFI2 } & Serum albumin & 10.2 & $35.0 \%$ \\
\cline { 2 - 3 } & Karnofsky Index & 0.9 & \\
\hline \multirow{2}{*}{$\begin{array}{l}\text { Disease } \\
\text { burden }\end{array}$} & Karnofsky Index & 0.5 & \multirow{2}{*}{$5.4 \%$} \\
\hline \multirow{2}{*}{ Symptoms } & $\begin{array}{l}\text { Heart attack/ } \\
\text { revascularization }\end{array}$ & -8.3 & \multirow{2}{*}{$23.9 \%$} \\
\cline { 2 - 3 } & $\begin{array}{l}\text { Refusal to use a } \\
\text { fistula }\end{array}$ & 7.4 & \multirow{2}{*}{} \\
\cline { 2 - 3 } & $\begin{array}{l}\text { Number of } \\
\text { cohabitants }\end{array}$ & -0.8 & \multirow{2}{*}{$15.3 \%$} \\
\cline { 2 - 3 } & Serum albumin & 12.6 & \\
\hline \multirow{2}{*}{$\begin{array}{l}\text { Kidney } \\
\text { disease }\end{array}$} & Karnofsky Index & 0.6 & \multicolumn{2}{|l|}{} \\
\cline { 2 - 3 } & Serum albumin & 9.2 & \\
\hline
\end{tabular}

patient in terms of dietary limitations, ability to travel, dependence on doctors and other health-care staff members, sexual life, and appearance. This finding is similar to that of studies conducted in Greece $(48.8 \pm 22.7 \text { points })^{33}$ and the United States $(52.0 \pm 30.0$ points $) .{ }^{34}$ Some authors have suggested that low scores in this domain are related to the dialysis type. ${ }^{35,36}$ In general, patients undergoing hemodialysis must visit health centers $2-3$ times per week for 3-4 hrs per session; this interferes with their professional and personal life because their autonomy is limited. Conversely, patients undergoing peritoneal dialysis can administer the treatments to themselves independently or with the help of a caregiver at home or at work, thus increasing the scores in this group. ${ }^{36,37}$ In this context, we recommend further research to consolidate or disprove this hypothesis.

The domain of the disease burden showed the extent to which kidney diseases interfere with the patient's life, which takes up too much of their time and creates frustration because they have to tend to the disease symptoms. The patients also perceive themselves as burdens to their families. In this domain, we found the lowest scores, with a mean of $35.0 \pm 27.5$ points. This result is similar to that of a population study from China, which reported a score of approximately $25 \pm 18$ points, ${ }^{38}$ and coherent with that 
of a multicenter study, which reported similar results with respect to the population of Japan. ${ }^{39}$ Some of the factors that may explain this finding are as follows: i) the type of health system, procedures and access barriers for diagnostic tests, and therapy are time-consuming for the patients, ii) limitations on mobility and to perform daily activities can result in a feeling of heteronomy, and iii) losing their jobs makes individuals see themselves as an economic burden to their families. In this regard, it has been reported that the employment rates for patients undergoing hemodialysis are as low as $18.9 \%$ in the United States, ${ }^{40} 33 \%$ in Finland, ${ }^{41}$ and $29.9 \%$ in India. ${ }^{42}$

In relation to the factors associated with the quality of life of patients undergoing hemodialysis, the serum albumin levels and Karnofsky Index stand out. In several studies, hypoalbuminemia has been associated with worse results with respect to the quality of life and with more hospitalizations and higher mortality rates. This may be attributed, at least partially, to the fact that serum albumin is an indicator of protein-energy wasting syndrome, a clinical condition that frequently develops in patients undergoing hemodialysis and has a great impact on their quality of life. ${ }^{43}$ With regard to the Karnofsky Index, it is worth mentioning that this index has been associated with the quality of life of different populations, including pediatric patients on chemotherapy, ${ }^{44}$ adults with lung cancer, ${ }^{45}$ and other patients undergoing hemodialysis, ${ }^{46}$ which proves its usefulness as a generic instrument to explain the construct.

The assessment of the HRQL scale's psychometric properties revealed excellent psychometric properties of reliability $(0.75-0.81)$, internal consistency $(100 \%)$, and discriminant validity $(100 \%)$ for all domains. These results, together with the international literature $34,47,48$ and the country's transcultural adaptation, ${ }^{9}$ show that the scale is adequate to explain HRQL to patients undergoing hemodialysis.

Among the limitations of this study, we found that the measurements were cross-sectional; hence, we were able to neither establish a causal link nor evaluate other psychometric properties of the scale, such as repeatability and interobserver reliability.

\section{Conclusion}

This study revealed the impact on the quality of life of Colombian patients with CKD undergoing hemodialysis. The most affected domain is the disease burden and the main associated factors are the serum albumin levels and Karnofsky Index. In addition, domains of physical and mental health, presented low scores, for such patients, the monitoring and care of their physical health should be complemented with the follow-up and care of their mental health. Moreover, KDQOL-36 has excellent properties of reliability, internal consistency, and discriminant power; thus, its use is recommended to monitor the quality of life of this population.

\section{Abbreviations}

CKD, Chronic kidney disease; HRQL, health-related quality of life; KDQOL-36, Kidney Disease Quality of Life Instrument.

\section{Acknowledgments}

We appreciate the support provided by patients Lorena Salazar Ospina, Johanna Marcela Vanegas Múnera.

\section{Funding}

This work was supported by the Administrative Department of Science, Technology and Innovation - Colciencias: Project 111577756947 and CODI-UdeA 2017-15526.

\section{Disclosure}

The authors report no conflicts of interest in this work.

\section{References}

1. Acuña L, Sánchez P, Soler LA, Alvis LF. Enfermedad renal en Colombia: prioridad para la gestión de riesgo. Rev Panam Salud Publica. 2016;40:16-22.

2. Hill NR, Fatoba ST, Oke JL, et al. Global prevalence of chronic kidney disease-A systematic review and meta-analysis. PLoS One. 2016;11 (7):1-18. doi:10.1371/journal.pone. 0158765

3. Jager KJ, Fraser SDS. The ascending rank of chronic kidney disease in the global burden of disease study. Nephrol Dial Transplant. 2017;32:121-128. doi:10.1093/ndt/gfw330.

4. Global burden of disease. Global, regional and national age-sex specific all-cause and cause-specific mortality for 240 causes of death, 1990-2013: a systematic analysis for the global burden of disease study 2013. Lancet. 2015;385(9963):117-171. doi:10.1016/S0140-6736(14)61682-2

5. National institute of diabetes and digestive and kidney diseases. Kidney disease statistics for the United States. [On line]; 2018 September. Available from: https://www.niddk.nih.gov/health-informa tion/health-statistics/kidney-disease. Accessed November 29, 2019.

6. Lopera-Medina MM. La enfermedad renal crónica en Colombia: necesidades en salud y respuesta del Sistema General de Seguridad Social en Salud Rev. Rev Gerencia Politicas salud. 2016;15(30):212-233. doi:10.11144/Javeriana.rgyps15-30.ercc

7. González MC, Rosa G, Ferreiro A. El registro latinoamericano de diálisis y transplante renal: la importancia del desarrollo de los registros nacionales en latinoamérica. Nefrología Latinoamérica. 2017;14 (1):12-21. doi:10.1016/j.nefrol.2016.12.002

8. Contreras F, Esguerra G, Espinosa JC, Gutierrez C, Fajardo L. Calidad de vida y adhesión al tratamiento en pacientes con insuficiencia renal crónica en tratamiento de hemodiálisis. Univ Psychol. 2006;5(3):487499 
9. Chaves K, Duarte A, Vesga J. Adaptación transcultural del cuestionario KDQOL SF 36 para evaluar calidad de vida en pacientes con enfermedad renal crónica en Colombia. Revista Med. 2013;21(2):34 42.

10. Li PK T, Chow KM. Infectious complications in dialysis- epidemiology and outcomes. Nature Rev Nephrol. 2012;8(2):77-88. doi:10.1038/nrneph.2011.194.

11. Grupo de la OMS sobre la calidad de vida. La gente y la salud.¿Qué calidad de vida? Rev Inter Desarrollo Sanitario. 1996;17(4).

12. World Health Organization. WHOQOL: measuring quality of life. [On line]; 2018 September. Available from: https://www.who.int/healthinfo/ survey/whoqol-qualityoflife/en/. Accessed November 29, 2019.

13. Consiglio E, Belloso WH. Nuevos indicadores clínicos, la calidad de vida relacionada con la salud. Rev Medicina (Buenos Aires). 2003;63:172-178.

14. Cardona JA, Higuita LF. Impacto del VIH/SIDA sobre la calidad de vida:metaanálisis 2002-2012. Rev Esp Salud Pública. 2014;88(1):87101. doi:10.4321/S1135-57272014000100006

15. Albañil T, Ramírez M, Crespo R. Análisis de la calidad de vida en pacientes en hemodiálisis ambulatoria y su relación con el nivel de dependencia. Enferm Nefrol. 2014;17(3):167-174. doi:10.4321/ S2254-28842014000300002

16. Hall RK, Luciano A, Pieper C, Colón-Emeric CS. Association of kidney disease quality of life (KDQOL-36) with mortality and hospitalization in older adults receiving hemodialysis. BMC Nephrol. 2018;19(11):2-9. doi:10.1186/s12882-017-0801-5

17. Zúñiga C, Dapueto J, Müller H, Kirsten L, Alid R, Ortiz L. Evaluación de la calidad de vida en pacientes en hemodiálisis crónica mediante el cuestionario "Kidney Disease Quality of Life (KDQOL-36)". Rev Med Chile. 2009;137(2):200-207. doi:10.4067/ S0034-98872009000200003

18. Barros L, Herazo Y, Aroca G. Calidad de vida relacionada con la salud en pacientes con enfermedad renal crónica. Rev Fac Med. 2015;63(4):641-647. doi:10.15446/revfacmed.v63.n4.49805

19. Yepes CE, Jaramillo MM, Orozco BRO, et al. Calidad de vida en pacientes con enfermedad renal crónica sin diálisis ni trasplante de una muestra aleatoria de dos aseguradoras en salud. Medellín, Colombia, 2008. Nefrología. 2009;29(6):548-556. doi:10.3265/ Nefrologia.2009.29.6.5490.en.full

20. Fondo Colombiano de enfermedades de alto costo. Situación de la enfermedad renal crónica, la hipertensión arterial y la diabetes mellitus en Colombia [Internet] Bogotá. Ministerio de Salud y protección social; 2017. revised en agosto del 2018, citado en agosto del 2018. Disponible en: https:/cuentadealtocosto.org/site/images/ Publicaciones/Situacion_ERC_HA_DM_Colombia_2016.pdf.

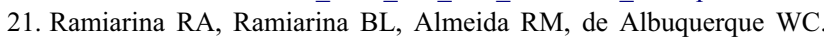
Comorbidity adjustment index for the International classification of diseases,10th revision. Rev Saúde Pública. 2008;42(4):590-597. doi:10.1590/S0034-89102008000400003

22. Puiggròs C, Lecha M, Rodríguez T, Pérez C, Planas M. El índice de Karnofsky como predictor de mortalidad de pacientes en nutrición enteral domiciliaria. Nutr.Hosp. 2009;24(2):154-160.

23. EuroQol Research Foundation. EQ-5D-3L User Guide. Versión 5.1. Holanda: EuroQol Research Foundation; 2015.

24. Thaweethamcharoen T, Srimongkol W, Noparatayaporn P, et al. Validity and reliability of KDQOL-36 in Thai kidney disease patient. Value Health Reg Issues. 2013;2(1):98-102. doi:10.1016/j. vhri.2013.02.011

25. Hays R, Kallich J, Mapes D, Coons S, Amin N, Carter W. Kidney Disease Quality of Life Short from (KDQOL-SFTM), Version 1.3:A Manual for Use and Scoring.1.3 Edition. Washington, DC: Rand; 1997.

26. Cohen DE, Lee A, Sibbel S, Benner D, Brunelli SM, Tentori F. Use of the KDQOL-36 ${ }^{\mathrm{TM}}$ for assessment of health-related quality of life among dialysis patients in the United States. BMC Nephrol. 2019;20 (1):112. doi:10.1186/s12882-019-1295-0
27. Tannor EK, Archer E, Kapembwa K, Van Schalkwyk SC, Davids MR. Quality of life in patients on chronic dialysis in South Africa: a comparative mixed methods study. BMC Nephrol. 2017;18(1):4. doi:10.1186/s12882-016-0425-1

28. Kim K, Kag GW, Woo J. The quality of life of hemodialysis patients is affected not only by medical but also psychosocial factors: a canonical correlation study. J Korean Med Sci. 2018;33(14):1-11. doi:10.3346/jkms.2018.33.e111

29. Sullivan JE, Choi NG, Vasquez CE. Psychosocial depression interventions for dialysis patients, with attention to Latinos: a scoping review. Res Social Work Pratice. 2019;20:10. doi:10.1177/ 1049731518820134

30. Ramakrishnan K, Bond TC, Claxton A, Kootsikas M, Agnese W, Sibble S. Clinical characteristics and outcomes of end-stage renal disease patients with self-reported pruritus symptoms. Int $J$ Nephrol Renovasc Dis. 2014;7:1-12. doi:10.2147/IJNRD.S52985.

31. Mathur VS, Lindberg J, Germain M. A longitudinal study of uremic pruritus in hemodialysis patients. Clin J Am Soc Nephrol. 2010;5 (8):1410-1419. doi:10.2215/CJN.00100110

32. Simonsen E, Komenda P, Lerner B, et al. Treatment of uremic pruritus: a systematic review. Am J Kidney Dis. 2017;70(5):638655. doi:10.1053/j.ajkd.2017.05.018

33. Kontodimopoulos N, Niakas D. Determining the basic psychometric properties of the Greek KDQOL-SFTM. Qual Life Res. 2005;14 (8):1967-1975. doi:10.1007/s11136-005-3868-6

34. Peipert JD, Bentler PM, Klicko K, Hays RD. Psychometric properties of the kidney disease Quality of Life 36-Item Short-Form Survey (KDQOL-36) in the United States. Am J Kidney Dis. 2018;71 (4):461-468. doi:10.1053/j.ajkd.2017.07.020

35. Wright LS, Wilson L. Quality of life and self-efficacy in three dialysis modalities: incenter hemodialysis, home hemodialysis, and home peritoneal dialysis. Nephrol Nurs J. 2015;42(5):463476.

36. Fructuoso M, Castro R, Oliveira L, Prata C, Morgado T. Quality of life in chronic kidney disease. Rev Nefrología. 2011;31(1):91-96. doi:10.3265/Nefrologia.pre2010.Jul.10483

37. Zazzeroni L, Pasquinelli G, Nanni E, Cremonini V, Rubbi I. Comparison of quality of life in patients undergoing hemodialysis and peritoneal dialysis: a systematic review and meta-analysis. Kidney Blood Press Res. 2017;42(4):717-727. doi:10.1159/ 000484115

38. Chow SK, Tam BM. Is the kidney disease quality of life-36 (KDQOL-36) a valid instrument for Chinese dialysis patients? $B M C$ Nephrol. 2014;15:199. doi:10.1186/1471-2369-15-199

39. Fukuhara S, Lopes AA, Bragg-Gresham JL, et al. Health-related quality of life among dialysis patients on three continents: the dialysis outcomes and practice patterns. Kidney Int. 2003;64(5):1903-1910. doi:10.1046/j.1523-1755.2003.00289.x

40. Kutner N, Bowles T, Zhang R, Huang Y, Pastan S. Dialysis facility characteristics and variation in employment rates: a national study. Clin J Am Soc Nephrol. 2008;3(1):111-116. doi:10.2215/ CJN.02990707

41. Helanterä I, Haapio M, Koskinen P, Grönhagen-Riska C, Finne P. Employment of patients receiving maintenance dialysis and after kidney transplant: a cross-sectional study from Finland. Am J Kidney Dis. 2012;59(5):700-706. doi:10.1053/j.ajkd.2011.08.025

42. Lakshmi BS, Kumar ACV, Reddy H, et al. Employment status of patients receiving maintenance dialysis - peritoneal and hemodialysis: a cross-sectional study. Indian J Nephrol. 2017;27(5):384. doi:10.4103/ijn.IJN_151_16

43. Ohri-Vachaspati P, Sehgal AR. Quality of life implications of inadequate protein nutrition among hemodialysis patients. J Ren Nutr. 1999;9(1):9-13. doi:10.1016/S1051-2276(99)90016-X 
44. Baggott CR, Dodd M, Kennedy C, et al. An evaluation of the factors that affect the health-related quality of life of children following myelosuppressive chemotherapy. Support Care Cancer [En Linea]. 2011;19(3):353-361. doi:10.1007/s00520-010-0824-y

45. Mohan A, Mohan C, Bhutani M, et al. Quality of life in newly diagnosed patients with lung cancer in a developing country: is it important? Eur J Cancer Care (Engl). 2006;15(3):293-298. doi:10.1111/j.1365-2354.2006.00654.x

46. Arogundade FA, Zayed B, Daba M, Barsoum RS. Correlation between Karnofsky performance status scale and short-form health survey in patients on maintenance hemodialysis. J Natl Med Assoc. 2004;96(12):1661-1667.
47. Chen JY, Choi EP, Wan EY, et al. Validation of the disease-specific components of the Kidney Disease Quality of Life-36 (KDQOL-36) in Chinese patients undergoing maintenance dialysis. PLoS One. 2016;11(5):1-13. doi:10.1371/journal.pone.0155188

48. Dehesa-López E, Correa-Rotter R, Olvera-Castillo D, González-Parra C, Baizabal-Olarte R, Orozco-Vega R. Transcultural adaptation and validation of the Mexican version of the kidney disease questionnaire KDQOL-SF36 version 1.3. Qual Life Res. 2017;26(1):193-198. doi:10.1007/s11136-016-1365-8

\section{Publish your work in this journal}

Patient Preference and Adherence is an international, peer-reviewed, open access journal that focusing on the growing importance of patient preference and adherence throughout the therapeutic continuum. Patient satisfaction, acceptability, quality of life, compliance, persistence and their role in developing new therapeutic modalities and compounds to optimize clinical outcomes for existing disease states are major areas of interest for the journal. This journal has been accepted for indexing on PubMed Central. The manuscript management system is completely online and includes a very quick and fair peer-review system, which is all easy to use. Visit http:// www.dovepress.com/testimonials.php to read real quotes from published authors. 